\title{
Variations in oxytocin, vasopressin and neurophysin con- centrations in the bovine ovary during the oestrous cycle and pregnancy
}

\author{
D. Claire Wathes, R. W. Swann and B. T. Pickering \\ Department of Anatomy, The Medical School, Bristol BS8 ITD, U.K.
}

\begin{abstract}
Summary. Bovine ovaries were obtained from the abattoir and corpora lutea were classified as: (1) early luteal phase (approximately Days 1-4); (2) mid-luteal phase (Days 5-10); (3) late luteal phase (Days 11-17); (4) regressing (Days 18-20) and (5) pregnant (Days 90-230). In addition, preovulatory follicles and whole ovaries without luteal tissue were collected. Concentrations of oxytocin, vasopressin, bovine neurophysin I and progesterone were measured in each corpus luteum by radioimmunoassay. Progesterone and neurophysin I levels increased from Stage 1 to Stage 2, plateaued during Stage 3 and declined by Stage 4. Oxytocin and vasopressin concentrations increased from Stage 1 to Stage 2 but declined during Stage 3 and were low (oxytocin) or undetectable (vasopressin) in follicles, whole ovaries and pregnancy corpora lutea. Therefore the concentrations of both peptide hormones were maximal during the first half of the cycle and declined before those of progesterone. The high concentration of oxytocin within the corpus luteum coupled with the presence of bovine neurophysin I suggests that oxytocin is synthesized locally.
\end{abstract}

\section{Introduction}

Oxytocin and vasopressin have been identified in bovine corpora lutea (Fields, Eldridge, Fuchs, Roberts \& Fields, 1983; Wathes, Swann, Birkett, Porter \& Pickering, 1983a; Wathes et al., 1983b). Oxytocin levels were higher in non-pregnant than in pregnant cows, but as material from a number of animals was pooled in these studies no information is available on the concentrations within individual ovaries, and it is not known whether these vary during the cycle. However, Schams (1983) has demonstrated higher plasma oxytocin levels in the cow during the early- and mid-luteal phase and similar results have been recorded for the ewe (Webb, Mitchell, Falconer \& Robinson, 1981; Sheldrick \& Flint, 1981; Schams, Prokopp \& Barth, 1983).

The bovine ovary also contains neurophysin (Wathes et al., 1983a) which is synthesized as part of the same precursor molecule as oxytocin (Land et al., 1983). Flint \& Sheldrick (1982) have demonstrated an arterial-venous difference in oxytocin concentration across the ovary but not across the head of the ewe during the luteal phase. Both these pieces of evidence suggest that the bovid corpus luteum can synthesize oxytocin, although final proof of this hypothesis is still awaited. The aim of the present study was to see how ovarian oxytocin and vasopressin concentrations alter during the oestrous cycle and pregnancy. 


\section{Materials and Methods}

Collection of ovaries. Ovaries were obtained from mature Holstein-Friesian type cows at the local abattoir. Corpora lutea from non-pregnant animals were classified into four stages by a careful examination of the reproductive tract as described and validated by Ireland, Murphee \& Coulson (1980). Briefly, Stage 1 includes the interval between ovulation and the time when the epithelium grows over the rupture point. During Stage 2 the corpus luteum is enclosed in epithelium, blood vessels are visible around the periphery and the apex is red. In Stage 3 the blood vessels extend over the apex of the corpus luteum and the internal appearance of the corpus luteum assumes an even orange-yellow colour. In Stage 4 the ovaries contain at least one large follicle and the corpus luteum has decreased in size and has no blood vessels visible on the surface. Ireland et al. (1980) estimated that the days of the cycle corresponding to these different stages were as follows: Stage 1, Days 1-4; Stage 2, Days 5-10; Stage 3, Days 11-17; Stage 4, Days 18-20. Corpora lutea were also collected from mid- to late-pregnant cows in which the duration of pregnancy was estimated from the crownrump length of the fetus. In addition preovulatory follicles and whole ovaries from cyclic cows containing follicles but not luteal tissue were obtained. Great care was taken to exlude from the study any cows in which either the ovaries or uterus had an abnormal appearance.

Treatment of ovaries. Whole ovaries were frozen on solid $\mathrm{CO}_{2}$ immediately after collection (10$20 \mathrm{~min}$ from slaughter) and stored at $-20^{\circ} \mathrm{C}$. After partial thawing, the corpora lutea or preovulatory follicles were dissected from the rest of the ovarian stroma and weighed. The earlier classification was checked by bisecting the corpus luteum. A small piece (10-20 mg wet weight) was removed for progesterone analysis. The remainder (still mainly frozen) was sliced into cold extraction medium consisting of $15 \%(\mathrm{v} / \mathrm{v})$ trifluoroacetic acid, $5 \%(\mathrm{v} / \mathrm{v})$ formic acid, $1 \%(\mathrm{w} / \mathrm{v})$ sodium chloride in $1 \mathrm{M}-\mathrm{HCl}$ (Walsh \& Niall, 1980) and homogenized. Extraction was performed on individual corpora lutea as described by Wathes et al. (1983a). After rotary evaporation the extract was freeze dried and divided into aliquots for radioimmunoassay (RIA).

Radioimmunoassays. Aliquots of each freeze-dried tissue extract were measured in specific RIAs for oxytocin, arginine vasopressin and bovine neurophysin I (Wathes et al., 1983a).

The progesterone content of the tissue was estimated by a scaled-down version of the technique described by Axelson, Schumacher, Sjövall, Gustafsson \& Lindell (1975). The extraction medium $(1.5 \mathrm{ml}$ chloroform : methanol, $1: 1 \mathrm{v} / \mathrm{v})$ was added to the frozen tissue sample $(10-20 \mathrm{mg})$ which was then homogenized for two 15 -sec bursts. The homogenate was placed in an ultrasonic bath for 15 min, mixed, then centrifuged at $10000 \mathrm{~g}$ for $3 \mathrm{~min}$ to remove the sediment. The supernatant was dried down under a stream of air and the extract was redissolved in $1 \mathrm{ml}$ progesterone assay buffer. Progesterone was measured by a specific RIA as described by Wathes \& Porter (1982). Recovery losses were estimated by adding $\left[{ }^{3} \mathrm{H}\right]$ progesterone to a similar amount of luteal tissue and recoveries were found to be $85.4 \pm 2 \cdot 16 \%$.

Extracts from all cows were measured in the same RIA for each hormone. In each case they diluted in parallel with the standard curve. Within-assay coefficients of variation were: oxytocin, $9.9 \%$; vasopressin, $5 \cdot 2 \%$; bovine neurophysin $I, 7 \cdot 5 \%$, progesterone, $9 \cdot 3 \%$. The sensitivities of the assays were $5 \mathrm{pg}$ oxytocin/tube, $2 \cdot 5 \mathrm{pg}$ vasopressin/tube; $25 \mathrm{pg}$ bovine neurophysin $\mathrm{I} / \mathrm{tube}$ and $15 \mathrm{pg}$ progesterone/tube.

High-performance liquid chromatography (HPLC). Portions of the peptide extract from selected cows were subjected to HPLC separation as described previously (Swann, Gonzalez, Birkett \& Pickering, 1982; Wathes \& Swann, 1982). HPLC fractions were tested in radioimmunoassays for oxytocin and vasopressin.

Statistics. Groups were compared using Student's $t$ test. 


\section{Results}

The visual classification of the corpora lutea was supported by the data on their weight and progesterone content (Table 1). The size and progesterone contents of the corpora lutea removed at each stage increased between Stages 1 and $2(P<0.001$ and $P<0.01)$, remained at a similar level during Stage 3 and then dropped precipitously by Stage $4(P<0.001)$. Progesterone levels in pregnant cows were similar to those in mid-cycle.

Table 1. Hormone content of the corpora lutea and ovaries of cows at different stages of the oestrous cycle

\begin{tabular}{|c|c|c|c|c|c|c|c|c|c|c|}
\hline \multirow{2}{*}{$\begin{array}{c}\text { Stage of } \\
\text { cycle } \\
\text { (days) }\end{array}$} & \multirow{2}{*}{$\begin{array}{l}\text { No. } \\
\text { of } \\
\text { CL }\end{array}$} & \multirow{2}{*}{$\begin{array}{l}C L \\
w t \\
(g)\end{array}$} & \multicolumn{2}{|c|}{ Progesterone } & \multicolumn{2}{|c|}{ Oxytocin } & \multicolumn{2}{|c|}{$\begin{array}{c}\text { Bovine } \\
\text { neurophysin I }\end{array}$} & \multicolumn{2}{|c|}{$\begin{array}{c}\text { Arginine } \\
\text { vasopressin }\end{array}$} \\
\hline & & & $\mathrm{nmol} / \mathrm{g}$ & $\mathrm{nmol} / \mathrm{CL}$ & $\mathrm{pmol} / \mathrm{g}$ & $\mathrm{pmol} / \mathrm{CL}$ & $\mathrm{pmol} / \mathrm{g}$ & $\mathrm{pmol} / \mathrm{CL}$ & $\mathrm{fmol} / \mathrm{g}$ & $\mathrm{fmol} / \mathrm{CL}$ \\
\hline $\begin{array}{c}1 \\
(1-4)\end{array}$ & 6 & $\begin{array}{r}2.46 \\
\pm 0.29\end{array}$ & $\begin{array}{c}58 \cdot 2 \\
\pm 8 \cdot 27\end{array}$ & $\begin{array}{c}129.4 \\
\pm 28.62\end{array}$ & $\begin{array}{c}486 \\
\pm 60 \cdot 2\end{array}$ & $\begin{array}{c}1231 \\
\pm 247 \cdot 4\end{array}$ & $\begin{array}{r}142.0 \\
\pm 27 \cdot 3\end{array}$ & $\begin{array}{r}369.3 \\
\pm 96.9\end{array}$ & $\begin{array}{c}128 \\
\pm 40 \cdot 8\end{array}$ & $\begin{array}{c}329 \\
+106.9\end{array}$ \\
\hline$\stackrel{2}{2}$ & 7 & $\begin{array}{r}5.81 \\
\pm 0.60\end{array}$ & $\begin{array}{c}133.6 \\
\pm 12.50\end{array}$ & $\begin{array}{r}775.9 \\
+109.7\end{array}$ & $\begin{array}{c}1774 \\
\pm 125 \cdot 3\end{array}$ & $\begin{array}{r}10150 \\
\pm 1014\end{array}$ & $\begin{array}{r}194.6 \\
\pm 18.9\end{array}$ & $\begin{array}{l}1074 \cdot 5 \\
\pm 77 \cdot 1\end{array}$ & $\begin{array}{c}243 \\
\pm 31 \cdot 4 \dagger\end{array}$ & $\begin{array}{c}1336 \\
\pm 124 \cdot 0\end{array}$ \\
\hline $\begin{array}{c}3 \\
(11-17)\end{array}$ & 10 & $\begin{array}{r}6.49 \\
\pm 0.50\end{array}$ & $\begin{array}{l}134 \cdot 5 \\
\pm 9 \cdot 86\end{array}$ & $\begin{array}{r}871 \cdot 3 \\
\pm 93 \cdot 8\end{array}$ & $\begin{array}{c}986 \\
+223.8\end{array}$ & $\begin{array}{r}6719 \\
\pm 1795\end{array}$ & $\begin{array}{r}153.8 \\
\pm 45.8\end{array}$ & $\begin{array}{r}775.2 \\
+240.8\end{array}$ & $\begin{array}{r}68 \cdot 1 \\
\pm 25 \cdot 2\end{array}$ & $\begin{aligned} & 496 \\
\pm & 217 \cdot 2\end{aligned}$ \\
\hline$\stackrel{4}{4}$ & 6 & $\begin{array}{r}1.74 \\
\pm 0.53\end{array}$ & $\begin{array}{r}8.6 \\
+4.07\end{array}$ & $\begin{array}{c}20 \cdot 3 \\
+10 \cdot 59\end{array}$ & $\begin{array}{r}55 \cdot 4 \\
+20 \cdot 6\end{array}$ & $\begin{array}{r}105.4 \\
\pm 72.6\end{array}$ & $\begin{array}{r}8.9 \\
+3.56\end{array}$ & $\begin{array}{c}21 \cdot 1 \\
\pm 15 \cdot 17\end{array}$ & $<40 \dagger$ & $<80$ \\
\hline $\begin{array}{l}\text { Pregnant } \\
\quad(90-230)\end{array}$ & 8 & $\begin{array}{r}5.77 \\
\pm 0.26\end{array}$ & $\begin{array}{c}115.4 \\
\pm 14.79\end{array}$ & $\begin{array}{c}657.0 \\
\pm 93.11\end{array}$ & $\begin{array}{c}7.7 \\
\pm 1.92\end{array}$ & $\begin{array}{r}44.9 \\
\pm 11.7\end{array}$ & $\begin{array}{c}1.4 \\
\pm 0.29\end{array}$ & $\begin{aligned} & 8.0 \\
\pm & 1.56\end{aligned}$ & $<40$ & $<80$ \\
\hline $\begin{array}{l}\text { Whole } \\
\text { ovary* }\end{array}$ & 4 & $\begin{array}{r}9.4 \\
\pm 2.03\end{array}$ & $\begin{array}{c}3 \cdot 2 \\
\pm 0.89\end{array}$ & $\begin{array}{c}35.0 \\
+19.30\end{array}$ & $\begin{array}{r}3.26 \\
\pm 1.92\end{array}$ & $\begin{array}{r}28.6 \\
\pm 15.29\end{array}$ & $\begin{array}{c}0.34 \\
\pm 0.268 \ddagger\end{array}$ & $\begin{array}{c}2.4 \\
\pm 1.61 \ddagger\end{array}$ & $<40$ & $<80$ \\
\hline $\begin{array}{l}\text { Preovulatory } \\
\text { follicle }\end{array}$ & 2 & $\begin{array}{r}2.26 \\
\pm 0.26\end{array}$ & \multicolumn{2}{|c|}{ Not measured } & $\begin{array}{r}0.49 \\
\pm 0.25\end{array}$ & $\begin{array}{r}1.19 \\
\pm 0.71\end{array}$ & $<0.004$ & $<0.008$ & $<40$ & $<80$ \\
\hline
\end{tabular}

Values are mean \pm s.e.m.

* Whole ovaries contained small follicles but no luteal tissue.

† Two cows had much higher AVP concentrations which were not included in the calculation of the mean values. These were, Stage 2: content $2316 \mathrm{fmol} / \mathrm{g}$, total $13801 \mathrm{fmol} /$ corpus luteum; Stage $4:$ content $3416 \mathrm{fmol} / \mathrm{g}$, total 13800 $\mathrm{fmol} /$ corpus luteum.

¥ One cow had a higher neurophysin I concentration which was not included in the calculation of the mean values. The content was $11.4 \mathrm{pmol} / \mathrm{g}$ and the total amount per ovary was $158.8 \mathrm{pmol}$.

Concentrations of oxytocin, vasopressin and bovine neurophysin I are also given in Table 1 as the mean \pm s.e.m. at each stage. Oxytocin contents were higher in Stage 2 than Stage 1, but showed a significant decline $(P<0.025)$ by Stage 3 and were low in Stage 4 . The maximum amount of oxytocin measured in a single corpus luteum was $18.5 \mu \mathrm{g}$. A significant positive correlation $(P<$ 0.05 ) between oxytocin and progesterone contents was found at Stages 1 and 2 but not at Stage 3. Examination of the data showed that this was because the Stage 3 corpora lutea fell into two groups: 5 of the corpora lutea contained high concentrations of both oxytocin $(1584 \pm 192 \mathrm{pmol} / \mathrm{g})$, and progesterone $(115.1 \pm 10.8 \mathrm{nmol} / \mathrm{g})$, whereas in the other 5 the oxytocin content was significantly lower ( $388 \pm 99.7 \mathrm{pmol} / \mathrm{g}, P<0.001)$ although the progesterone content was actually higher $(153.9 \pm 11.4 \mathrm{nmol} / \mathrm{g}, P<0.05)$ and the size remained unchanged $(6.04 \pm 0.93 \mathrm{~g}$, low oxytocin group; $6.94 \pm 0.43 \mathrm{~g}$, high oxytocin group). Oxytocin was present at much lower concentrations in the corpora lutea of mid- to late-pregnant cows. The range in individual animals was $0.7-15.1 \mathrm{pmol} / \mathrm{g}$ and showed no trend with stage of pregnancy although animals at gestational ages of 90-230 days were examined. Oxytocin concentrations were also very low in whole ovaries not containing corpora lutea and in follicles that were thought to be preovulatory (Table 1).

Vasopressin levels followed a similar trend to those of oxytocin with significantly higher levels in Stage 2 than Stage 1 and a decline $(P<0.005)$ by Stage 3. Concentrations $(\mathrm{fmol} / \mathrm{g})$ in all but one Stage-3 cow (range $<23-113, \mathbf{N}=9 ; 274, \mathbf{N}=1$ ) were lower than in all Stage-2 cows (range 161$379, \mathbf{N}=6 ; 2316, \mathbf{N}=1$ ), suggesting that the vasopressin content drops before that of oxytocin. In 
Stage 4, vasopressin could only be measured in 2 out of 6 animals and it was undetectable in all the corpora lutea from pregnant animals and in all the whole ovaries and preovulatory follicles. However, 2 cows (one Stage 2 and one early Stage 4) showed anomalous and much higher levels. The concentration of vasopressin in the corpora lutea of these animals was 2.3 and $3.4 \mathrm{pmol} / \mathrm{g}$ respectively, whereas in all other cows it was $<0.38 \mathrm{pmol} / \mathrm{g}$. Confirmation of the data from these two animals was obtained by chromatographing part of the extract on HPLC (Text-fig. 1). This showed peaks of immunoreactive vasopressin of the predicted size in the characteristic elution position for this hormone in both cows.

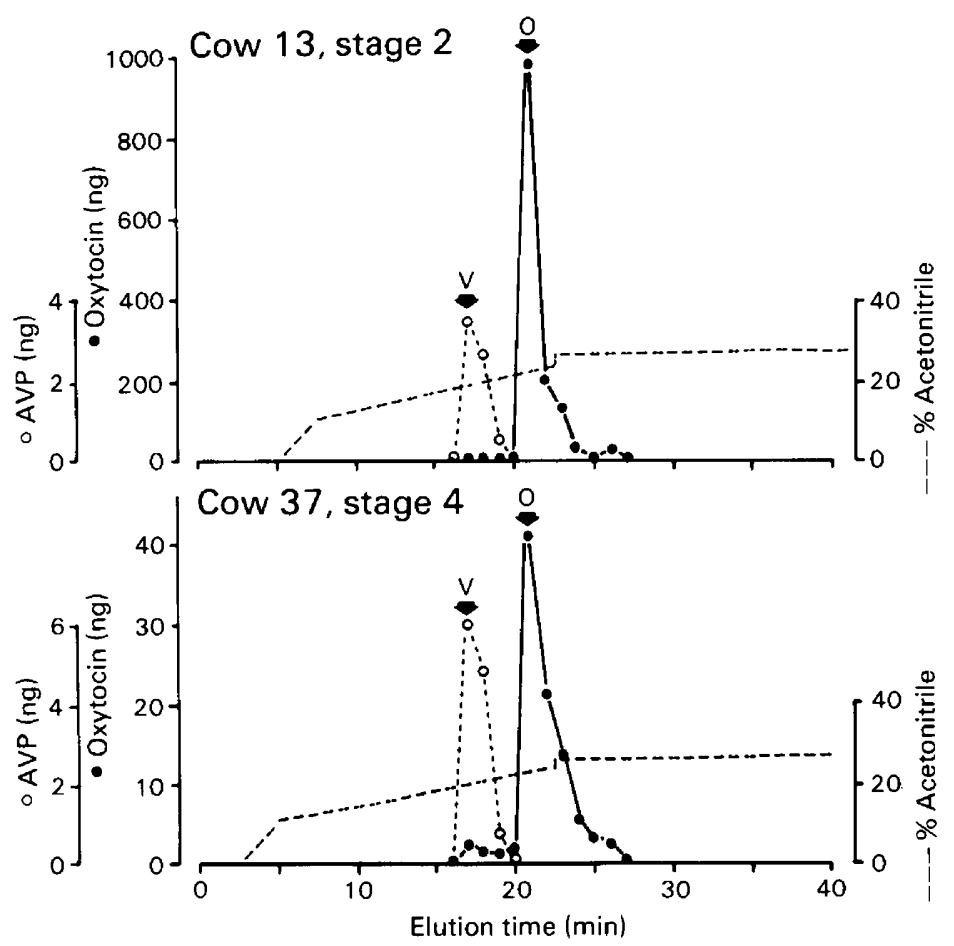

Text-fig. 1. Immunoreactivity profile of extracts from two bovine corpora lutea after separation on HPLC. The column was run at $1 \mathrm{ml} / \mathrm{min}$ with an increasing gradient of acetonitrile. Fractions $(1 \mathrm{ml})$ were collected and measured in RIAs for arginine vasopressin (AVP) and oxytocin. V and O indicate the elution positions of the AVP and oxytocin standards in the same system.

The bovine neurophysin I levels were also maximal during Stage 2 and then declined, with low values during pregnancy (Table 1). During Stages 1, 3 and 4 the neurophysin concentrations were significantly correlated with the oxytocin concentrations $(P<0 \cdot 05$, Stage $1 ; P<0.01$, Stages 3 and 4). However, there was no such correlation during Stage $2(r=0.017, \mathrm{~N}=7)$. The molar ratio of neurophysin to oxytocin within individual corpora lutea at different stages was also examined. During Stages 1-3 values from different cows in the same group showed good agreement, but there was a significant $(P<0.01)$ decrease in the ratio between Stages 1 and 2 (molar ratios neurophysin : oxytocin: Stage 1, 0.29 \pm 0.04 ; Stage $2,0 \cdot 11 \pm 0.01$; Stage $3,0.13 \pm 0.01$ ). In the other samples (Stage 4, pregnancy corpora lutea and whole ovaries) the concentrations of both peptides were much lower and there was considerable variation in the ratio between different animals in the same group (molar ratios: Stage 4, $0.33 \pm 0.08$; pregnant, $0.29 \pm 0.06$; whole ovaries, $0.92 \pm 0.64$ ). 


\section{Discussion}

The validity of this study is dependent on the accuracy with which the corpora lutea were dated and this subject therefore merits a careful consideration. In Table 2 a comparison has been made between the sizes and progesterone contents of corpora lutea in this study with previously reported values. In general the agreement is good, but there are exceptions which require comment. In Stage 1 the average weight of the corpora lutea was greater than in other studies. However, the classification is unlikely to be at fault at this stage because both the ovulation point and red coloration were obvious visually. A possible reason for the difference is that, in the present study, the whole ovary was frozen and the corpora lutea were dissected out later. During Stage 1 the corpus luteum still has a soft consistency and may contain a pool of blood. When dissecting the ovary fresh it is more difficult to be certain that all the tissue has been obtained, particularly if the corpus luteum is removed at laparotomy rather than at slaughter. During Stage 4, both the size and the progesterone content were at the lower end of previously reported values. In this case the difference was probably due to positive selection towards corpora lutea that had obviously regressed, although in all cases they were obtained before the animal had re-ovulated. Finally, the progesterone values during Stage 2 tended to be higher than in other studies. Direct comparisons are difficult to make because of the differences in methodology between this and the majority of the earlier studies. However, two authors reported much higher progesterone contents on Day 11 (Gomes, Estergreen, Frost \& Erb, 1963; $211 \mathrm{nmol} / \mathrm{g}$; Hafs \& Armstrong, 1968; $146 \mathrm{nmol} / \mathrm{g}$ ) so that a difference of 1 day in defining the stages made a large difference to the mean progesterone values in Stage 2 . We feel, therefore, that the 4 stages used in this study, which were based on the visual appearance of the ovary, do represent genuinely different phases in the lifespan of the corpus luteum. As the normal length of the oestrous cycle in the mature cow varies from 18 to 24 days (Dziuk, 1973), the precise allocation of days to each stage is more arbitrary.

Table 2. A comparison of the size and progesterone content of bovine corpora lutea between the present and previous studies

\begin{tabular}{|c|c|c|c|c|c|c|}
\hline \multirow{3}{*}{$\begin{array}{l}\text { Stage of cycle } \\
\text { (days) }\end{array}$} & \multicolumn{3}{|c|}{ Weight of CL (g) } & \multicolumn{3}{|c|}{ Progesterone content of $\mathrm{CL}(\mathrm{nmol} / \mathrm{g})$} \\
\hline & \multicolumn{2}{|c|}{$\begin{array}{l}\text { Composite value from } \\
\text { other studies* }\end{array}$} & \multirow{2}{*}{$\begin{array}{l}\text { Present } \\
\text { study† }\end{array}$} & \multicolumn{2}{|c|}{$\begin{array}{l}\text { Composite value from } \\
\text { other studies* }\end{array}$} & \multirow{2}{*}{$\begin{array}{l}\text { Present } \\
\text { study }\end{array}$} \\
\hline & Mean & Range & & Mean & Range & \\
\hline $\begin{array}{r}\text { Stage } 1 \\
(1-4)\end{array}$ & $1 \cdot 3$ & $0.5-2 \cdot 2$ & $2 \cdot 4 \pm 0 \cdot 29$ & $57 \cdot 5$ & $12-150$ & $58 \cdot 2 \pm 8 \cdot 27$ \\
\hline $\begin{array}{l}\text { Stage } 2 \\
\quad(5-10)\end{array}$ & $5 \cdot 1$ & $1.9-6.8$ & $5 \cdot 8 \pm 0 \cdot 60$ & 97.0 & $44-118$ & $133.6 \pm 12 \cdot 50$ \\
\hline $\begin{array}{l}\text { Stage } 3 \\
\quad(11-17)\end{array}$ & $5 \cdot 2$ & $3 \cdot 5-9 \cdot 7$ & $6 \cdot 5 \pm 0 \cdot 50$ & $85 \cdot 2$ & $19-232$ & $134 \cdot 5 \pm 9 \cdot 86$ \\
\hline $\begin{array}{l}\text { Stage } 4 \\
\quad(18-21)\end{array}$ & $3 \cdot 1$ & $1 \cdot 3-5 \cdot 0$ & $1.7 \pm 0.53$ & $59 \cdot 1$ & $6-131$ & $8.6 \pm 4.07$ \\
\hline
\end{tabular}

* Taken from Erb \& Stormshak (1961); Mares, Zimbleman \& Casida (1962); Gomes et al. (1963); Foley, Black, Black, Damon \& Howe (1964); Hafs \& Armstrong (1968); Veenhuizen, Wagner \& Tonkinson (1972); Axelson et al. (1975) and Ireland et al. (1980).

+ Mean \pm s.e.m.

The highest levels of all three peptides were found during the first half of the luteal phase. These data are in agreement with those of Schams (1983) who found the highest circulating oxytocin levels in the cow between Days 5 and 13 of the cycle. As half of the corpora lutea in Stage 3 had lower oxytocin concentrations even though the progesterone content and size gave no indication of regression it appears that the level of oxytocin normally declines before that of progesterone. This pattern differs from that reported by Flint \& Sheldrick (1983) in ewes following luteal regression 
induced by cloprostenol, an analogue of PGF- $2 \alpha$. They found that treatment on Day 8 of the cycle produced an immediate fall in jugular progesterone levels while oxytocin levels showed an initial increase and remained elevated for $24 \mathrm{~h}$ longer. Preliminary observations in the cow have shown that cloprostenol treatment causes an immediate increase in luteal oxytocin secretion. Maximal levels were reached in 5-10 min but secretion had dropped to basal values within $12 \mathrm{~h}$ (Walters, Schams, Bullermann \& Schallenberger, 1983).

In the neurohypophysial system oxytocin and bovine neurophysin I are part of a common precursor linking one molecule of each peptide (Land et al., 1983). Processing of the precursor leads to the presence of equimolar amounts of the two components in the neurohypophysis. Although in the present study we have found more neurophysin than we did initially (Wathes et al., 1983a), the molar ratio of neurophysin to oxytocin in the corpus luteum of non-pregnant cows was still considerably less than $1(0 \cdot 11-0 \cdot 33)$. At present we cannot be sure that this apparent discrepancy is not due to technical difficulties: there may be differential extraction of the two polypeptides with the extractability varying at different stages of the cycle. On the other hand, although the immunoreactive neurophysin in the corpus luteum has chromatographic properties similar to those of authentic bovine neurophysin I (Wathes et al., 1983a) it is possible that the molecules are not identical and the radioimmunoassay does not give an accurate reflection of the amount of luteal neurophysin. Whatever the cause, there does appear to be a shift in the neurophysin/oxytocin ratio during the cycle. This could reflect changes in the pattern of precursor processing or degradation within the large luteal cells which is where the polypeptides are stored and probably synthesized (S. E. F. Guldenaar, D. C. Wathes \& B. T. Pickering, unpublished observations).

The present study has confirmed two of our preliminary findings (Wathes et al., 1983a). Firstly, oxytocin concentrations in the bovine corpus luteum are much lower during pregnancy than in the cycle. We did not have any samples available from early pregnancy, but in the ewe Sheldrick \& Flint (1983) have demonstrated that luteal oxytocin concentrations drop at the same time (about Day 14) in pregnant and non-pregnant animals. Secondly, we have again isolated a peptide with the RIA and HPLC characteristics of vasopressin. Luteal vasopressin levels were highest during the early luteal phase and were undetectable during pregnancy.

The physiological significance of the high luteal oxytocin and vasopressin levels remains unclear. Tan, Tweedale \& Biggs (1982) showed that oxytocin may have a direct action on progesterone production by dispersed bovine luteal cells as concentrations of oxytocin below 40 $\mathrm{mU} / \mathrm{ml}(67 \mathrm{pmol} / \mathrm{ml})$ stimulated progesterone production whereas oxytocin in excess of $800 \mathrm{mU} / \mathrm{ml}$ $(1344 \mathrm{pmol} / \mathrm{ml})$ inhibited the response of the cells to hCG. These concentrations are within the range found in the bovine corpus luteum and this action could therefore be physiological. The relationship between oxytocin and progesterone levels seems to vary at different times in the cycle. During the early luteal phase both hormones are present in large amounts and increase in synchrony. In the late luteal phase, our data suggest that the fall in oxytocin may be followed by an increase in progesterone before this too declines, but as luteal concentrations can only be measured at one time in any one cycle this point is difficult to confirm. In the rat testis vasopressin is more potent than oxytocin in suppressing testosterone production (Adashi \& Hsueh, 1981) and when given to heifers in the early luteal phase, vasopressin can depress plasma progesterone levels (McCann, O’Horo, Milvae \& Hansel, 1981).

Exogenous oxytocin can undoubtedly inhibit the formation of normal bovine corpora lutea but it has this effect oniy if administered between Days 3 and 6 of the cycle (Hansel \& Wagner, 1960). When given later in the luteal phase it does not alter oestrous cycle length (Hansel \& Wagner, 1960) and may actually increase the progesterone content of the corpora lutea (Mares \& Casida, 1963). Our data and those of Schams (1983) indicate that oxytocin levels in the ovary and blood decline before luteal regression begins. It is probable that the remaining luteal oxytocin undergoes a positive feedback relationship with uterine PGF- $2 \alpha$ as suggested by Flint $\&$ Sheldrick (1983) for the ewe, leading to a more rapid completion of luteolysis. Nevertheless, it seems likely that the large amounts of oxytocin present in the first half of the cycle have an additional and as yet undefined function. 
We thank Miss J. Creek and Mr P. Rees for excellent technical assistance; Professor D. G. Porter for helpful criticism of the paper; Mrs S. Somers for typing the manuscript; and the staff of Hendy \& Hill Ltd for co-operation in obtaining the ovaries. The work was supported in part by the M.R.C., A.R.C. and the Wellcome Trust.

\section{References}

Adashi, E.Y. \& Hsueh, A.J.W. (1981) Direct inhibition of testicular androgen biosynthesis revealing antigonadal activity of neurohypophysial hormones. Nature, Lond. 293, 650-652.

Axelson, M., Schumacher, G., Sjövall, J., Gustafsson, B. \& Lindell, J.O. (1975) Identification and quantitative determination of steroids in bovine corpus luteum during oestrous cycle and pregnancy. Acta endocr., Copenh. 80, 149-164.

Dziuk, P. (1973) Occurrence, control and induction of ovulation in pigs, sheep and cows. In Handbook of Physiology, Section 7. Endocrinology, Vol. II, Female Reproductive System, Part 1, pp. 143-152. Ed. R. O. Greep. American Physiological Society, Washington, D.C.

Erb, R.E. \& Stormshak, F. (1961) Progestins in corpora lutea, ovaries and adrenals after estrous and breeding of normal and abnormal cows. J. Dairy Sci. 44, 888896.

Fields, P.A., Eldridge, R.K., Fuchs, A.-R., Roberts, R.F. \& Fields, M.J. (1983) Human placental and bovine corpora luteal oxytocin. Endocrinology 112, 1544 1546.

Flint, A.P.F. \& Sheldrick, E.L. (1982) Ovarian secretion of oxytocin is stimulated by prostaglandin. Nature, Lond. 297, 587-588.

Flint, A.P.F. \& Sheldrick, E.L. (1983) Evidence for a systemic role for ovarian oxytocin in luteal regression in sheep. J. Reprod. Fert. 67, 215-225.

Foley, R.C., Black, D.L., Black, W.G., Damon, R.A. \& Howe, G.R. (1964) Ovarian and luteal tissue weight in non-pregnant and pregnant heifers and cows with normal reproductive histories. J. Anim. Sci. 23, 752757.

Gomes, W.R., Estergreen, V.L., Frost, O.L. \& Erb, R.E. (1963) Progesterone levels in jugular and ovarian venous blood, corpora lutea, and ovaries of the non pregnant bovine. J. Dairy $S c i .46,553-558$.

Hafs, H.D. \& Armstrong, D.T. (1968) Corpus luteum growth and progesterone synthesis during the bovine estrous cycle. J. Anim. Sci. 27, 134-141.

Hansel, W. \& Wagner, W.C. (1960) Luteal inhibition in the bovine as a result of oxytocin injections, uterine dilatation and intrauterine infusions of seminal and preputial fluids. J. Dairy $S c i$. 43, 796-805.

Ireland, J.J., Murphee, R.L. \& Coulson, P.B. (1980) Accuracy of predicting stages of bovine estrous cycle by gross appearance of the corpus luteum. J. Dairy Sci. 63, 155-160.

Land, H., Grez, M., Ruppert, S., Schmale, H., Rehbein, M., Richter, D. \& Schutz, G. (1983) Deduced amino acid sequence from the bovine oxytocin-neurophysin 1 precursor cDNA. Nature, Lond. 320, 342-344.

Mares, S.E. \& Casida, L.E. (1963) Effect of exogenous oxytocin on the progesterone content of the bovine corpus luteum. Endocrinology 72, 78-82.

Mares, S.E., Zimbleman, R.G. \& Casida, L.E. (1962) Variation in progesterone content of the bovine corpus luteum of the estrual cycle. J. Anim. Sci. 21, 266-271.
McCann, J.P., O'Horo, M.T., Milvae, R.A. \& Hansel, W. (1981) Plasma levels of $\mathrm{LH}$, progesterone and cortisol in heifers following vasopressin injections. J. Anim. Sci. 53, Suppl. 1, 347, Abstr.

Schams, D. (1983) Oxytocin determination by radioimmunoassay. III. Improvement to subpicogram sensitivity and application to blood levels in cyclic cattle. Acta endocr., Copenh. 103, 180-183.

Schams, D., Prokopp, S. \& Barth, D. (1983) The effect of active and passive immunization against oxytocin on ovarian cyclicity in ewes. Acta endocr., Copenh. 103, 337-344.

Sheldrick, E.L. \& Flint, A.P.F. (1981) Circulating concentrations of oxytocin during the estrous cycle and early pregnancy in sheep. Prostaglandins 22, 631636.

Sheldrick, E.L. \& Flint, A.P.F. (1983) Luteal concentrations of oxytocin decline during early pregnancy in the ewe. J. Reprod. Fert. 68, 477-480.

Swann, R.W., Gonzalez, C.B., Birkett, S.D. \& Pickering, B.T. (1982) Precursors in the biosynthesis of vasopressin and oxytocin in the rat. Biochem. J. 208, 339349.

Tan, G.J.S., Tweedale, R. \& Biggs, J.S.G. (1982) Effects of oxytocin on the bovine corpus luteum of early pregnancy. J. Reprod. Fert. 66, 75-78.

Veenhuizen, E.L., Wagner, J.F. \& Tonkinson, L.V. (1972) Corpus luteum response to 6-chloro $\Delta^{6}-17$ acetoxyprogesterone and $\mathrm{hCG}$ in the cow. Biol. Reprod. 6, 270-276.

Walsh, J.R. \& Niall, H.D. (1980) Use of an octadecylsilica purification method minimises proteolysis during isolation of porcine and rat relaxins. Endocrinology 107, 1258-1260.

Walters, D.L., Schams, D., Bullermann, B. \& Schallenberger, E. (1983) Pulsatile secretion of gonadotropins, ovarian steroids and ovarian oxytocin during luteolysis in the cow. Biol. Reprod. 28, Suppl. 1, 142, Abstr.

Wathes, D.C. \& Porter, D.G. (1982) Effect of uterine distension and oestrogen treatment on gap junction formation in the myometrium of the rat. J. Reprod. Fert. 65, 497-505.

Wathes, D.C. \& Swann, R.W. (1982) Is oxytocin an ovarian hormone? Nature, Lond. 297, 225-227.

Wathes, D.C., Swann, R.W., Birkett, S.D., Porter, D.G. \& Pickering, B.T. (1983a) Characterization of oxytocin, vasopressin and neurophysin from the bovine corpus luteum. Endocrinology 113, 693-698.

Wathes, D.C., Swann, R.W., Hull, M.G.R., Drife, J.O., Porter, D.G. \& Pickering, B.T. (1983b) Gonadal sources of the posterior pituitary hormones. Prog. Brain Res. 60, 513-520.

Webb, R., Mitchell, M.D., Falconer, J. \& Robinson, J.S. (1981) Temporal relationships between peripheral plasma concentrations of oxytocin, progesterone and 13,14-dihydro-15-keto prostaglandin $F_{2_{\alpha}}$ during the oestrous cycle and early pregnancy in the ewe. Prostaglandins 22, 443-454. 